\title{
New Industrial Conditions of Sustainable Development of Mineral Resource Dependent Russian Economy in High Volatility Conditions
}

\author{
Tatiana Skryl ${ }^{1}$, Evgeniya Shavina ${ }^{2}$, and Elena Dotsenko ${ }^{2, *}$ \\ ${ }^{1}$ Plekhanov Russian University of Economics, Academic Department of Political Economy and \\ History of Economic Science, 117997, Moscow, 36 Stremyanny lane, Russia \\ ${ }^{2}$ Plekhanov Russian University of Economics, Academic Department of Economic Theory, 117997, \\ Moscow, 36 Stremyanny lane, Russia
}

\begin{abstract}
The conditions for the transition to sustainable development and new industrial transformation for resource-dependent countries are closely linked. With the increasing volatility of the world market of raw materials and finance, the innovative modernization of the extractive industries, as the basis of the new industrialization of the economy, is experiencing significant difficulties. The article analyzes the problems of transition of the resourcedependent Russian economy to sustainable development, associated with the slowdown of the process of new industrialization in the context of the world market volatility. The authors assessed the new industrialization of the Russian economy following the 5-year period of sanctions imposed by Western countries. The article provides a theoretical review of the concept of the influence of sanctions on transition to sustainable development. The authors concluded that the mineral resources export-oriented strategy of the Russian economy still gives positive results, although the internal structure of the Russian economy has not changed significantly.
\end{abstract}

\section{Introduction}

The world economy is now a complex integrated mechanism where the global economic actors operate. In the current circumstances, no country, even the largest, is profitable to resist international integration. If we consider the concept of integration itself, we can say that it is a complex, but at the same time contradictory process. On the one hand, the rapid expansion of inter-state economic relations facilitates interaction between economic actors, makes it possible to access the advanced achievements of the planetary scale, providing resource savings and stimulating economic growth. On the other hand, it is also an important reason for increased competition between countries. Economic theory knows many forms of competition in different markets. In the current conditions, the most effective form is sanctions, as one of the forms of competition for a share in the global market [1].

Sanctions can be viewed in different ways. First, sanctions are actions or measures taken by the government on the termination (or threatened termination) of a traditional commercial

\footnotetext{
${ }^{*}$ Corresponding author: ktyf110372@yandex.ru
} 
or financial relations with political objectives. Second, sanctions are a special type of tax to Finance foreign policy activities for the imposing country, but at the same time very unevenly distributed in society [2]. Sanctions have always been imposed by a dominant country to force a weaker country to choose an imposed path of development, to change the regime or to submit to external decisions, to change domestic policy. Today, sanctions are a tool when war is expensive and dangerous, and diplomacy fails.

The history of sanctions really begins in ancient times and continues to this day. As a rule, the initiator of the sanctions was the country occupying a dominant position either in the territory or in the scale of the economy in comparison with the target country, which made it impossible to apply retaliatory measures $[3,4,5]$.

Most of the sanctions were imposed unilaterally. Nowadays we can observe, at first only from the United States introduced sanctions measures, but then they were joined by the countries of Western Europe. In the Russian Federation, the President received the right to apply economic sanctions in 2006, when law No. 281 - FZ "On special economic measures" was adopted.

Initially, the sanctions concerned only the trade sector between countries and influenced the structure of exports and imports. Restrictions on trade generally act selectively, and in a globalized world lead to the redirection of trade flows, not its termination; change in import and export prices at the same time for the sanctioned country depends on the specific market and often minimal.

Financial sanctions are now more common. It is safe to say that financial sanctions have an advantage over trade sanctions in several areas:

- losses from trade sanctions in an authorized country are more or less evenly distributed throughout the population, while financial sanctions concentrate on a narrow circle close to the authorities;

- losses from trade sanctions within the country, imposing them, are concentrated in certain areas of industry, in fact, some companies are forced to subsidize the policy of the whole state. Financial sanctions are distributed much more evenly and, in case of refusal of public loans, the losses are borne by the same structure (state), which can benefit from sanctions [3, p.105].

The debate about the effectiveness of sanctions began after the First World War and continues to this day [6]. The success of sanctions depends on the goal, on average; sanctions are successful in about a third of cases. As an example, the US embargo against Cuba, which continues to this day. It is estimated that the direct damage to the Cuban economy from sanctions for half a century exceeded 1 trillion dollars in current prices [7]. However, the main goal of sanctions - changing the political regime - has not yet been achieved.

\section{Materials and Methods}

To analyze the state and structure of the Russian economy at the end of the five-year period of sanctions, let us first consider the main characteristics of Russia. Let us start with the main - Russia is the largest country in the world in terms of territory, which is located on two continents (Europe and Asia), the area of Russia is more than 17.1 million square kilometers, which is more than $1 / 8$ of the total population of the planet Earth. Russia has just over 144 million inhabitants as of 2018. Russia owns about $30 \%$ of the world's natural resources and the World Bank estimates that it is worth about $\$ 75$ trillion. The most important resources are oil, natural gas and precious metals. Russia has the world's largest natural gas reserves and is the world's largest exporter of natural gas and the second largest exporter of oil. Russia has an exceptionally powerful military industry, producing high-tech military equipment, including combat aircraft, weapons, missiles, nuclear submarines and ships. Export of military equipment in 2016 amounted to 15.7 billion dollars. The fact that Russia is 
recognized as the largest country in the world on a territorial scale gives it a certain economic and political tool, a kind of lever of control [8-14].

In 2017, Russia's GDP was estimated at $\$ 1.58$ trillion, which is the 11 th in the world. GDP growth in 2017 amounted to $1.5 \%$. GDP per capita is $\$ 10,608$, which is only 68 th in the world. In 2017 , the inflation rate was $2.5 \%$. The unemployment rate in Russia is quite low, and in 2017 amounted to $4.5 \%$ [14].

Despite the fact that the structure of the Russian economy is highly differentiated by industries, Russian exports, which in 2016 were estimated at 285 billion us dollars, were produced only for the following products: oil and petroleum products, natural gas, metals, wood and wood products, chemicals.

Main export collaborates [14]:

1. European Union - $45 \%$

2. China $-10 \%$

3. Belarus $-5 \%$

4. Turkey $-5 \%$

5. South Korea $-3.5 \%$

6. Other countries $-31.5 \%$

Table 1. Overview of imports / exports by year for Russia in the period 2005-2016 (billions of dollars). Calculated by the authors based on Rosstat data [14].

\begin{tabular}{|c|c|c|c|c|c|c|c|c|}
\hline Year & $\mathbf{2 0 0 9}$ & $\mathbf{2 0 1 0}$ & $\mathbf{2 0 1 1}$ & $\mathbf{2 0 1 2}$ & $\mathbf{2 0 1 3}$ & $\mathbf{2 0 1 4}$ & $\mathbf{2 0 1 5}$ & $\mathbf{2 0 1 6}$ \\
\hline Export & 302 & 397 & 517 & 525 & 527 & 498 & 344 & 285 \\
\hline Import & 171 & 229 & 306 & 316 & 315 & 287 & 183 & 182 \\
\hline Surplus/Deficit & 131 & 168 & 211 & 209 & 212 & 211 & 161 & 103 \\
\hline $\begin{array}{c}\text { GDP per capita } \\
(\$)\end{array}$ & 10.2 & 10.0 & 11.2 & 11.6 & 11.8 & 11.6 & 11.3 & 11.3 \\
\hline
\end{tabular}

Looking at the structure of the trade balance, we see that Russia sells a large surplus of its natural resources and exports most of them, while imports are much lower and have a technological structure.

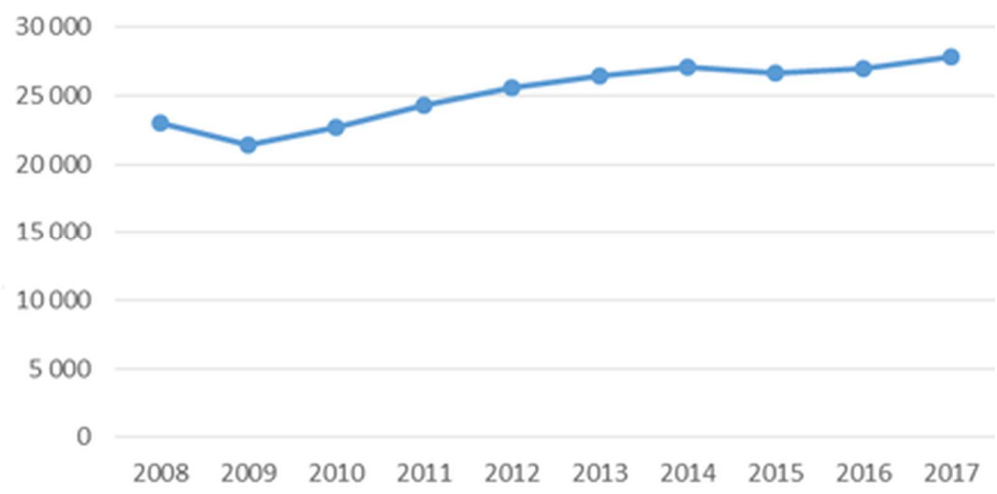

Fig. 1. Russia's GDP (per capita) by year (compiled by the authors on the basis of Rosstat data) [14].

As can be seen from figure 1, there is a positive trend. It is important to note that over the past 10 years, Russia's GDP has been quite stable, because of the demonstration of a strong export-oriented raw materials strategy.

International sanctions against Russia were imposed during the Ukrainian crisis of 2014. Many European and world countries imposed sanctions against individuals, companies and officials of Russia and Ukraine: the United States of America, the European Union and other 
countries, as well as international organizations. Russia introduced counter-sanctions in response, banning the import of certain types of food from the European Union, the United States, Norway, Canada and Australia [15-20].

If you look at the beginning of 2014 since the introduction of sanctions, exports to Russia from European countries decreased by $\$ 8.6$ billion in one quarter. Nevertheless, it is also obvious that exports from the same countries increased to other countries, that is, European exports increased by $3.5 \%$ over the same period. Of course, we cannot say that the countersanctions did not harm the European countries, but it is obvious that the exporting countries were able to compensate for the decline in exports to Russia by exports to other countries [14].

Table 2. Export of European countries to Russia and other countries in 2014 [15].

\begin{tabular}{|c|c|c|}
\hline Country & $\begin{array}{c}\text { Total exports in } \\
\text { million euros }\end{array}$ & $\begin{array}{l}\text { Export to Russia in } \\
\text { million euros }\end{array}$ \\
\hline Austria & 33037 & -360 \\
\hline Belgium & 88707 & -360 \\
\hline Bulgaria & 4859 & -41 \\
\hline Britain & 96345 & -333 \\
\hline Hungary & 20433 & -165 \\
\hline Germany & 278427 & -2566 \\
\hline Holland & 125648 & -590 \\
\hline Greece & 6379 & -24 \\
\hline Denmark & 20548 & -114 \\
\hline Ireland & 21107 & -78 \\
\hline Spain & 60276 & -301 \\
\hline Italy & 96151 & -668 \\
\hline Cyprus & 325 & -5 \\
\hline Latvia & 2589 & -87 \\
\hline Lithuania & 5415 & -374 \\
\hline Luxembourg & 3618 & -14 \\
\hline Malta & 536 & 0 \\
\hline Poland & 40223 & -521 \\
\hline Portugal & 11707 & -18 \\
\hline Romania & 12758 & -91 \\
\hline Slovakia & 16194 & -156 \\
\hline Slovenia & 6597 & -85 \\
\hline Finland & 13248 & -358 \\
\hline France & 109586 & -612 \\
\hline Croatia & 2364 & -21 \\
\hline Czechia & 32205 & -365 \\
\hline Sweden & 31179 & -196 \\
\hline Estonia & 2854 & -147 \\
\hline
\end{tabular}

The Russian economy, having certain advantages, still faced a number of difficulties. Given the imposition of sanctions on food imports, combined with the fall in oil prices and the weakening of the Russian ruble as the official currency, the Russian economy has received quite high inflation, that is, the overall rise in prices [16-22]. This is also seen in figure 2 below; it was from the beginning of the first sanctions in early 2014 that there was a slight increase in inflation, but after Russia introduced counter-sanctions to ban the import of certain types of food - it is obvious that this caused serious market turmoil and a significant increase in inflation, which amounted to $16 \%$ in March 2015 [23]. 


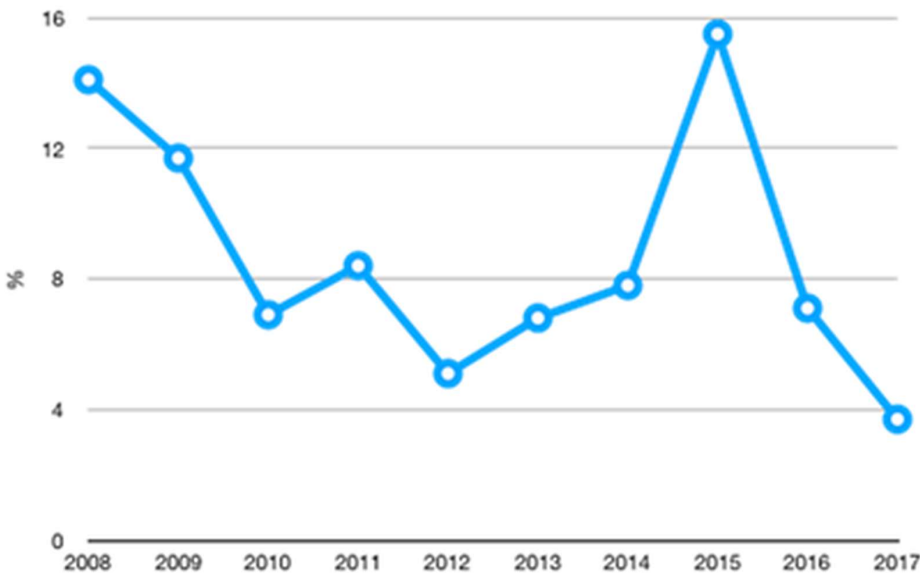

Fig. 2. Inflation rate in the Russian Federation in the period 2008-2017 (compiled by the authors based on Rosstat data) [14].

When we consider the factors affecting the competitiveness of the Russian economy, the key element is certainly the world oil prices. As noted above, oil is Russia's main export commodity. Oil prices fell from $\$ 115$ per barrel to $\$ 60$ per barrel at the end of 2014, which certainly contributes to the fall in the value of all Russian exports. In January 2016, the price of oil fell into the lowest pit, where the cost of 1 barrel was $\$ 27.1$. The fall in prices was caused by a strong increase in oil production in the US from oil shale, a rock that is very well suited for oil production. Due to the huge opportunities of the mining industry, the United States became independent of imported oil for several months, and Russia's excess oil was soon to enter the open market, pushing the price of oil down.

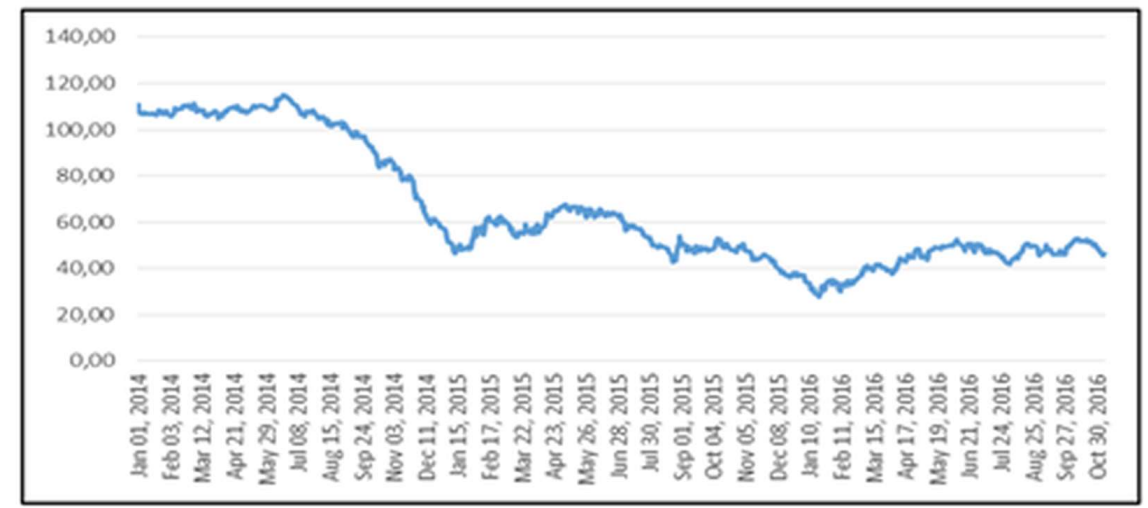

Fig. 3. The price of oil barrel, 2014-2016 (\$ US / barrel) [7].

The fall in oil prices on the world market also led to a significant drop in export revenues of the Russian Federation, which means a sharp drop in government revenues. Namely, oil exports account for almost $50 \%$ of government revenues. In order to continue financing the economy and cover the deficit in the state budget, as we see in figure 6 , the state had to disclose state reserves, so in 2015 and 2016 almost $2 / 3$ of the state reserves were spent from $\$ 87$ to $\$ 32$ billion, respectively [14].

In addition to dependence on the Russian economy from world oil prices, the ruble was also extremely sensitive to changes in the oil markets. At the beginning of 2014, when the dollar/ruble ratio was 33, while at the beginning of 2016 the Russian ruble was heavily 
devalued, so the ratio was more than 80 . As a result of the fall of the ruble, there was a rapid decline in investment, so that only in 2014, more than $\$ 150$ billion was withdrawn from Russia, while foreign investment fell by $30 \%$ [7, 24].

\section{Results and discussion}

If we hold the historical chronology of the imposition of sanctions against Russia, the history dates back to 1930, when the United States imposed a trade embargo forgive the USSR, which extended to all goods except grain.

As an example, the USA grain embargo against the military actions of the USSR in Afghanistan. Only direct us losses from this share amounted to more than $\$ 2$ billion.; even more importantly, American agricultural producers have lost a large market as a result, and still cannot return it, because this niche in the post-Soviet space was occupied by imports from other countries $[5,25]$.

Another example is the Jackson-Vanik amendment, which significantly limited the foreign economic relations of the USSR (abolished in 2012, but immediately replaced by similar restrictions under the Magnitsky list), and then supplemented in connection with the Ukrainian events, due to the annexation of the Crimea to Russia.

Now the USA President is constantly tightening sanctions in terms of cooperation between the two countries in the military-industrial complex and obtaining credit funds for the Russian economy. Since in theory, when imposing sanctions against one country, this country can find support in the face of another country. In particular, Russia has found it in the face of China, as this country does not impose and does not support anti-Russian sanctions. There, the Russian economy is looking for the optimal investor. Nevertheless, the USA does not stop at traditional sanctions instruments, now they impose sanctions directly on individuals and legal entities with any ties to the us jurisdiction, which cooperate with companies from Russia [9].

The negative aspects of this competitive sanctions struggle can be marked by the termination of joint developments in medicine, geological exploration, space exploration, where joint work would bring many benefits to the entire population and improve the quality of life in General [10]. Yes, in practice, we see that the sanctions are being tightened, supplemented, but in parallel, some of them are being lifted: the EU has eased some of the anti-Russian sanctions in the framework of its space program, the US has lifted some of the sanctions from Rosoboronexport in terms of contracts for the maintenance of helicopters in Afghanistan.

Of course, the actions of Western countries to tighten sanctions can be seen as the main widespread idea, which is aimed at countering the technological development of Russia. However, in our view, the reason for the sanctions is purely market-based.

In April 2017, an official UN report was presented which noted the effectiveness of the introduction of anti-Russian sanctions. The dry balance showed that in Russia the damage amounted to 52-55 billion dollars and other States that imposed sanctions this policy has caused losses in the amount of more than $\$ 100$ billion [13].

\section{Conclusion}

To revive and grow the Russian economy lacks three components of success: cheap investment, technology and skilled personnel.

Consider the situation in the agricultural market. In the country, due to the action of counter-sanctions, this market has increased significantly; the share of domestic goods in the consumer basket has increased. However, as we can see now, it was the effect of the first or 
second year of import substitution. Now agricultural market participants need either expansion of production or its modernization to produce the same product, but at a more competitive price or in a larger volume that the market requires. This requires, first of all, cheap investments, new technologies and qualified personnel.

The Russian economy in particular, its real sector has fallen into technological dependence on developed countries [11].

At the beginning of 2018, the structure of the Russian economy unfortunately did not change its shape 10 years ago [6]. The real sector is still struggling with financing. In other words, the real and financial markets are still not interconnected and represent two separate economic units. The task of the financial market to supply the real is not fulfilled. One of the reasons is the fact that banks overestimate risks due to the high volatility of the external environment and declare high unacceptable rates for business.

Why sanctions will continue: it is appropriate to recall the principle of decision-making in the United States. The completely decision-making process is based on the algorithm system 0 and 1, Yes and no. Judging by history, the US has a rich experience of imposing sanctions against other countries. Following the algorithm, if one of the tools of the sanctions struggle gave a positive result, then in a similar case this result should be repeated, if not, the algorithm goes the other way [4].

As we can see the Russian practice of sanctions, the desired effect of the Western countries have not achieved, especially in terms of restrictions on sources of Finance. Russia still does not run out of money for large-scale projects, especially with state participation. How it can be? The answer lies again in the logic of managerial decision-making, in particular in the manual management of the Russian economy. After all, the essence of some sanctions is the arrest of any assets that belong to businesspersons from the sanctions list. As a result, billions of funds can not be withdrawn from the country (because immediately be frozen in the accounts) begin to work within the country, financing large-scale projects.

This study was financed by a grant from the Plekhanov Russian University of Economics.

\section{References}

1. D. Halpern, Inside the Nudge Unit: How Small Changes Can Make a Big Difference (Ebury Press, London, 2016)

2. G. C. Hufbauer, J. J. Schott, K. A. Elliott, B. Oegg, Economic Sanctions Reconsidered (Peterson Institute for International Economics, Berlin, 2007)

3. G. C. Hufbauer, J. J. Schott, K. A. Elliott, B. Oegg, Economic Sanctions Reconsidered (Peterson Institute for International Economics, Stockholm, 1990)

4. R. Thaler, C. Sunstein, Nudge: Improving Decisions about Health, Wealth and Happiness (Yale University Press, Yale, 2008)

5. S. D. Bodrunov, New industrialization: prerequisites and approaches to implementation (Urals, Ekaterinburg, 2018)

6. V. V. Kolmakov, Vectors of institutional transformation of industry in the conditions of anti-Russian sanctions (Plekhanov Russian University of Economics, Moscow, 2018)

7. The world in Tables (IMF, Washington, 2016)

8. Guidelines for the development of the Russian economy. Collective monograph (Plekhanov Russian University of Economics, Moscow, 2018)

9. V.S. Osipov, A.V. Bogoviz, E.I. Semenova, Adv. Intel. Sys. Comp., 622, 58-64 (2018) 
10. M. Porter, Competition (Williams, Moscow, 2005)

11. V. Osipov, T. Skryl, A. Zeldner, MATEC Web Conf., 212, 04017 (2018)

12. T.V. Skryl, International Journal of Ecological Economics and Statistics, 38:2, 49-58 (2017)

13. Federal state statistics service (Rosstat, Moscow, 2018)

14. Directory by countries, exports by countries, URL: https://www.cia.gov/library/publications/the-world-factbook/rankorder/2078rank.html

15. K. Sen, J. Develop. St., 55:7, 1565-1583 (2019)

16. R. Wilson, An. Am. As. Geog., 109:2, 314-323 (2019)

17. R. Kozul-Wright, P. Fortunato, Glob. Pol., 10:1, 29-40 (2019)

18. R. Barldwin, The Great Convergence: Information Technology and the New Globalization (Harvard University Press, Boston, 2016)

19. J. Enos, W.-H. Park, The Adoption and Diffusion of Imported Technology (Croom, London, 1988)

20. G. Gereffi, Rev. Int. Pol. Ec., 21:1, 9-37 (2014)

21. E. Green, Eth. Rac.1 St., 42 :2, 178-197 (2019)

22. O. Krpec, V. Hodulak, Revista de Economia Politica, 39, 152-172 (2019)

23. R. Aidis, S. Estrin, T. Mickiewicz, J. Bus. Vent., 23, 656-672 (2008).

24. S. Braguinsky, S.Mityakov, Journal of Financial Economics, 117:1, 139-164 (2015)

25. V. S. Osipov, T. V. Skryl, N. A. Nevskaya, E. V. Shavina, International Business Management, 10:9, 1649-1657 (2016) 